\title{
Business Ethics Education
} in Banks - Levels and Methods of Education

Prof. Róża Milic-Czerniak Ph.D. | WSZMiJ0 w Katowicach Komisja Etyki Bankowej przy ZBP | r.milic.czerniak@gmail.com

\section{Abstract}

\section{Purpose}

The essay focuses on some important instruments and measures supporting the desired actual (and not just declared) ethical behavior in banking practices.

\section{| Methodology}

The essay first used a combination of comparisons to show similarities and differences between 10 banking codes of ethics in EU countries. Then qualitative analysis of indicators and scales assigned to bank rankings was also used to identify some possibilities to promote the ethical behavior of banks in more efficient ways.

\section{Findings}

Ethical behaviors in the banks, despite a high awareness of moral norms, are largely declarative rather than actual. In order to approximate the actual behaviors to the declared ones, further improvements need to be introduced in the methods and instruments of education (codes of ethics, bank rankings), along with encouraging the implementation of management practices consistent with ethical behavior. This should start with redefinition of the functioning of the bank, i.e. broadening the task of achieving ambitious outcomes by adding respect for ethical standards. 


\section{| Practical Implications}

Not every instrument of ethics education can be treated as directly useful in the process of training actual ethical behavior in banks. Some particular conditions must be taken into account that it should fulfill.

\section{| Originality}

The author has distinguished three levels in business ethics education: ethical awareness and ethically oriented behaviors, both declared and actual. The essay described the necessary conditions for utilization of some educational instruments of ethics in the process of implementing actual ethical behaviors in the banks.. Such an approach has not been found previously in the subject literature.

Key words: levels of ethics education, code of ethics, ranking of banks, corporate social responsibility

\section{JEL: M14}

\section{| Introduction}

Issues of ethics, ethical behavior of institutions, companies, workers, and to a lesser extent customers, permeates all levels of discussion, and it appears especially often in the context of the 2007-2009 financial crisis. That crisis appeared, as many authors agree, as a result of greed. It becomes obvious that despite all the regulations, recommendations, and instructions, the more accurate and intricate they were, the more frequently they were violated, and therefore did not guarantee respect for the ethical rules. Ethical behaviors of institutions are generally decisions made with regard to both their own needs and aspirations, and also to others referred to as stakeholders. Going beyond the framework of self-interest is sometimes referred to as taking into account „globally understood self-interest” (Reid in Young 2005: 6).

Ethical behaviors, as various studies have shown, are generally cost-effective, especially in the longer term. For example, a study by the London Institute of Business Ethics showed that companies using a code of professional ethics achieve higher profits, and both economic (EVA) and market (MVA) value added were higher in comparison with companies that have not explicitly declared an ethical way of doing business. A similar positive correlation between the ingrained culture of respect for the stakeholders (customers, employees and shareholders), as well as the increase in net income and share prices over eleven years was shown by professors JP Kotter and JL Heskett of Harvard Business School (Young 2005: 5). 
Unethical behaviors are usually associated with the decisions for immediate particular benefits to the companies, which leads to longer-term negative consequences. In recent years, there have been many examples of declining institutions that have made decisions aimed at showing higher current profits. The well known examples are Enron, Arthur Andersen and Worldcom. A more recent example is the Japanese company Olympus, in which three members of the board for 20 years have been hiding huge financial losses resulting from investments, overstating the value of companies that were taken over. After revealing this practice on Tuesday, November 8, 2011, the value of the Olympus shares fell by almost 30\% in one day. The shares of Japan's largest investment bank and insurer Nomura also fell by 15\% (to the lowest level since 1974), due to rumors that it was involved in the transactions of Olympus. The bank assured others that the company was only one of its customers; however it did not stop the slump (Piotrowski 2011). So a bank's reputation also depends on the reputation of the companies it supports.

Unprecedented customer behavior towards the largest U.S. banks should be interpreted as a turning point in the execution of ethical behavior by these institutions. This behavior was a negative reaction to an introduction by Bank of America of charges for using debit cards (\$5). It resulted in both protests against the behavior of banks, and also led through social media sharing to the exodus of customers from giant banks like Bank of America, Citibank, Chase and Wells Fargo to small local banks and credit unions. Within just a few weeks, more than 650,000 customers shifted their deposits (\$4.5 billion) to local banks, which did not gain so many customers in all of 2010. Supporters of the "Occupy Wall Street" movement proclaimed November 8th as "Bank Transfer Day", even though Bank of America, (like other large banks), withdrew from the planned charge for debit cards. (Przybylski 2011). A similar reaction with the transition of customers to local banks was also observed in Germany during the crisis, where the assets of German cooperative banks increased by $24 \%$ (Simon et al. 2009).

The rationale for making such a drastic decision by the customers of American banks was, however, not only financial benefits in the form of lower fees and higher interest on deposits. In their speeches, the customers stressed that they did not want to cooperate with a bank that was rescued by taxpayers' money and does not participate actively in supporting the development of the economy and additionally dismisses workers on a large scale. In addition, customers said that they preferred to work with credit unions and local banks that support local businesses. Customer behavior, therefore, did not concern only its own interests, but also the interests of two additional groups of stakeholders, namely employees and local communities. This specific experience teaching ethical behavior to the banks, and promoted by customers through social media, was very costly for the big banks. This is because it depleted their source of income directly, and also affected their reputations, which adversely affected the reconstruction of confidence in all banks that were weakened by the crisis.

The situation was also unprecedented in the UK because the relatively low satisfaction with the services of the largest banks. In 2002, "very satisfied" was only 30\% of HSBC and Lloyds TSB, 
$34 \%$ of Barclays and 36\% of NatWest customers, compared to $91 \%$ of customers of the small bank Smile. However, these low rankings have not coincided with the desire to change banks by customers, as they were traditionally strongly attached to their banks, which was compared to attachment to their pubs. The British Consumers Association actually intended to influence the decisions of individual customers about changing banks to break the monopoly of the largest banks (Garapich 2003: 11).

Similarly, the introduction of a study in January 2010 by the Polish Bank Association (PBA), "Recommendations on good practice in handling savings accounts for individuals in the Polish banking market", created in cooperation with the institutions of the European Union, which cedes formalities connected with the change to a new bank account has not had a positive response on a wider scale (Kuk 2010). Traditionally strong attachment of customers to the bank could be changed in a short time as a protest against unethical bank behavior, effectively supported by social media. The U.S. customers' justifications as extended to other stakeholders seem to be reliable as well.

Unethical behaviors cannot, however, be seen as limited to certain companies. Acceptance of unethical behavior already manifests itself in the process of looking for work. There are those Europeans, according to a global job seekers survey, that would decide to work for a company whose activities are unethical (31\%). Asians and Americans were ready to resign because of the principles in the name of employment less frequently $(19 \%)^{1}$.

Recapitulating these observations, one could conclude that attaching increasing significance to ethical behaviors in a workplace, particularly in the banking system, results not only from the fact that it is cost-effective, but also because unethical behaviors are very often rejected by customers. With that background, the following describes some important tools and measures supporting the desired ethical behavior in banking, namely:

- Canons of good banking practices (codes of ethics). These are the typical rules contained in the codes of ethics in the selected countries of the European Union (Holland with three codes, Finland, Luxemburg, Cyprus, Czech Republic, Slovenia, Hungary), their declarative character, supported by the necessary conditions for utilization of these codes in the process of implementing the ethical behavior;

- Ratings of banks. Rankings of the "best banks" according to "the quality of service for small and medium enterprises (SMEs)" and "rankings of the most responsible businesses" reporting their corporate social responsibility (CSR) including financial institutions, are published in widely accessible and popular professional journals and are frequently read by bank employees. On the grounds of an appropriate selection of indicators and the scales assigned to them (defined in terms of quality-analysis), these rankings could promote the ethical behavior of banks in a more efficient way.

1 According to monster.com. ab: Etyka firmy mniej ważna w Europie niż w USA i w Azji. Rzeczpospolita, 21 September, 2011, p. B11. 


\section{| Levels of ethical behavior and the shaping of business ethics}

What determines decisions concerning not only short-term interest, which affect the perception of the environment in business, and therefore influence ethical behavior? In the discussions on ethics in the life of the individual, led for centuries among philosophers, theologians, sociologists and economists, basic instincts are often isolated. These may be characterized as needs or internal motives such as greed, wickedness, and succumbing to their temptations is common. However, moral sense, willpower and nobility can tame these mundane instincts. Aristotle believed that people can get on the road to happiness, shaping their ethical habits. Hegel insisted that moral visions manifest themselves in the activities through willpower. Adam Smith believed that the inherent moral sense in a man may be a tendency to be overcome wickedness and avarice. Similarly, Habermas argued that we can impose "normativity" over the "factuality". Ethical behaviors are therefore not self-evident, concomitant with every human action, but on the contrary require extra effort, willpower, and understanding of moral principles.

Therefore in the process of moral development, certain levels are frequently isolated. Psychologist Lawrence Kohlberg identified six of them starting from the lowest, which consists of striving to avoid penalties. The next one concerns activities undertaken to meet one's own needs, and up to stage 6, where one is full of ethical behavior, consistent with the law as a conscious choice. Robert J. Spitzer identified four main driving forces of human actions: the achievement of immediate gratification, promotion and gaining advantage over others, doing good by respecting such principles as justice and community and participating in giving and receiving, and finally by living according to ideals (Young 2005: 8-12).

A short overview of different approaches to ethical behavior in human activities shows very clearly that ethics are not "given" to people once and for all, but they require proper upbringing, education and moral consciousness.

In a discussion on education in business ethics, three levels can be distinguished: ethical awareness, and ethically oriented behaviors declared and actual. Division into declared and actual behaviors is consistent with the distinction between standards recognized and assimilated as introduced by M. Ossowska. Recognition of moral norms does not equal their observance. Acquiring standards means respecting them in our own behavior (Ossowska 2005: 110). The level of awareness shows knowledge of the values, principles of ethical behavior and their importance in different areas of everyday life.

At the level of declarations, we can observe the acceptance of concrete ethical behavior and the willingness to incur certain expenses (time, cost, resignation of privileges, rewards). The last level represents the actual behavior and adherence to ethical principles. For example, this distinction shows how important it is for a bank employee to follow the values in life. Therefore if he considers relevant observance of moral principles in customer service (e.g. recommending 
certain products), then he should actually serve customers according to their needs and preferences and not his own benefits (e.g. the need to carry out a sales plan).

The ideal situation would be to achieve a 100\% rating for each of these levels, which would mean that every stakeholder of the bank is aware of the nature of ethical behavior, and also declares the ethical conduct and behaves in accordance with the declarations. In fact, such a standard level of ethical awareness does not cover the whole population. Behaviors on the level of declarations are rarer than the awareness of standards, and only a few people respect ethical standards in their daily behavior in the workplace.

The process of training and education of a human being is crucial in raising awareness of ethical behavior. In Poland, a special role in this process is connected, as Witold Kieżun explains, with "deeply rooted Catholic tradition, which is an important element of Catholic social teaching including the teaching of John Paul II" and the traditions of the social movement "Solidarity" (Kieżun 2008: 68). The process of ethical education from kindergartens to universities is also important, especially if it is consistent with the fundamental principles of education, for example in "The Principles for Responsible Management Education” (Gasparski 2008).

In the process of shaping ethical behavior in working life, an increasingly important role is played by the acts adopted at the European Union level as Directive 2010/76/UE, called Capital Requirements Directive III (CRD III). It relates to capital requirements and supervisory review of remuneration policies, particularly the salaries of employees having a significant impact on the bank's risk profile.

These regulations should reduce such spectacularly unethical behavior as that committed by the Societe Generale trader (Jerome Kerviel), who while desiring to earn huge profits for the bank bought too many risky assets causing a $€ 4.9$ billion loss. Yet he received an annual bonus of several hundred thousand euros (Stec 2011). There is also the widespread selling of banking products in an unethical manner. For examples, these unethical practices include lying to clients that loans can be sold only in packages with a credit card or bank account, and making unwanted solicitations for additional insurance products, to implement a sales plan and receive a bonus (Czubkowska 2009).

Developing the desired ethical behavior in the workplace is one of the most difficult learning processes, because ethical behaviors:

- Often stand in conflict with the particular interests of the employer, owner, employee or even customer;

- Are strongly determined by economic variables (losing job, lower wages, not receiving the premium), which provide a great excuse for unethical behavior;

- Appear in many repetitive, minor everyday situations at work where it is easier to "postpone" recognized values such as honesty, loyalty, truthfulness etc.; 
- Run under strong pressure in the immediate environment at work. Behavior at work is often characterized by a different logic than that of family life (e.g., "I act like that because we all do this at work, otherwise I would be a sucker for colleagues" or "I act like this because my superior requires it");

- Result from habits. Unethical behavior acquired in one job is transferred as a conscious or unconscious standard to other jobs.

Teaching ethics and business ethics in general, or giving examples of best practices is an excellent basis for developing ethical awareness; however, it does not translate directly into the ethics of behavior in business. This requires a tedious demonstration in various areas of enterprise including banking, with both positive and negative examples. This requires the creation of new habits, customs, new behaviors, even automated responses, and often just replacing the existing habits with ethical behaviors. The shaping of second nature is a tedious and lengthy process, which can be faster if it covers the entire business community, not individual employees, and its infrastructure, and therefore management methods.

An example was adopted by the commercial chain of Piotr i Pawel stores with orientation to customer experience as the main way of building competitive advantage. The process of teaching the new culture of customer service employees, according to a new philosophy of action, lasted 23 years among workers using it. Since even intensive training proved to be absolutely inadequate, it became the main barrier to the rapid development of business by opening new stores.

Another example would be General Electric Company, well known for implementing innovative methods of management. The GE brand was in fifth place among the top brands in the world in 2011 (Best 2011: 20). Implementing a code of ethics in this company required strong ethical leadership and also changes in the basic elements of management, including organizational structure and methods of remuneration. It took nine years to make natural the value of openness within General Electric, and over twenty years to make it commonly adopted throughout the whole company. This is because it required "a kind of tough battle against human nature and against the deep imbedded, corporative patterns of behavior" (Welch 2005: 48).

The process of ethical education is the process of increasing the size of these three groups (ethical awareness, and ethically oriented behaviors declared and actual) and closing the gap between them. Approaching an ideal level requires applying multiple, properly prepared instruments, such as the teaching of business ethics, and taking into account the principles of responsible management, promotion of business ethics in various rankings of banks, codes of ethics, and the implementation of management practices conducive to ethical behavior by the banks.

Developing ethical behaviors should be permanent and should touch the most basic activities in a professional workplace. Special attention in this article will be devoted to widely available training instruments connected with ethical behavior, such as the published rankings of the banks and their codes of ethics. 


\section{Principles of good banking practices /codes of ethics/as an instrument of stimulating ethical behaviors of banks}

Associations of banks in different countries have developed rules (canons) of good banking practices (also known as codes of ethics), sometimes not limited to one code (e.g. the Netherlands). Almost in every country, these rules concern respecting the confidentiality of personal data, building advertising messages, behavior of bank employees, handling complaints, bank relationships with clients and mutual relations between banks. Often they are a repetition of legal norms existing in a particular area. The rules covering customer relations usually emphasize the obligations of the bank and its employees towards customers. However, they do not describe the most ignored obligation to inform customers of the reasons for refusal to provide a specific service (such as about negative decisions concerning a loan application) because such an obligation does not exist. Bank-employee relationships are focused on the duties of the employee to the bank and its customers, but do not mention about the bank's obligations towards the employee. Sometimes these rules are preceded by an introduction of the outlined goal of formulating them.

These rules may or even should be different in different countries, since they evolve from differently conditioned cultural and economic environments. For example, this is evident in a specific code of conduct for small and medium enterprises developed by the association of Cypriot banks (Zdanowska 2011).

Principles of good banking practice to meet their basic function of regulating and encouraging banks and their stakeholders to adhere to ethical behavior should go beyond the law (to comply with legal norms they are obliged under the pressure of certain penalties). They should point to the unethical practices repeated in particular relationships that are due to the lower economic harm, the predictability of business behaviors which is important from the social perspective or are due to negligence of law in considering the regulation of behavior requiring processes resulting from globalization, crises etc.

Principles of good practices should include relevant aspects of the ethical behavior of all stakeholders, namely employees, customers, suppliers and competitors, local communities, and owners / investors. It is worth noting that the first four groups were mentioned by Porter as major competitive forces (Porter 1992). This meant treating them as rivals in competing for profits earned in the industry. Instead, according to the rules of business adopted at the meeting of the Caux Round Table (1994), businesses should expand their responsibility in shaping the future from the owners / investors to all stakeholders (Principle 1).

Rules included in the code of ethics should take into account the need for strict observance of legal regulations in each area of the bank, and also in the areas of laundering money, developing advertisements, conducting competitive struggles, selecting suppliers, servicing customer and managing employees. Compliance with the law should be the ethical foundation of each bank 
(Principle 4). In many situations, however, it is not enough. Principles of ethical behavior should also anticipate the trends in legislation, policy and banking supervision. They should include such behaviors as the right of clients to be fully informed about the conditions for granting loans or for the benefit of full-paid insurance. In accordance with Rule 3, business behavior should go beyond the letter of the law to the spirit of trust.

Banks are increasingly becoming canvassers in the sale of products of other financial institutions. This raises many questions about sales ethics as banks sell them to receive commissions, often without taking into account the risks associated with these products (mutual funds) and the interests of customers (selling insurance products attractive to the bank, not the customers who pay). This raises the need for recognition of the issues involved after a thorough analysis of the implementation of the Markets in Financial Instruments Directive (MiFID) obliging banks to act honestly, fairly and professionally while offering customers investment products within a set of Principles of Good Banking Practice. These principles, developed by the Banking Ethics Commission at the PBA, will be periodically reviewed, updated and supplemented in terms of changes in the functioning of the banking sector, and also in terms of improving corporate social responsibility that creates confidence in the banks.

Individual banks declare their behavior in accordance with the Principles of Good Banking Practice, and very often develop their own codes of ethics. However, there are no banks in which compliance with the principles contained in the codes would be enforced as consistently as the role of the job. What is more, there are no reactions towards manipulation by employees with accounts and reports to demonstrate the achievements expected by superiors. Uncontrolled pressure on the results somehow allows different "shortcuts", while at the same time there is no enforcement of ethical behavior. Implementing the principles of ethical behavior in the banks without the links with other areas of governance remains only a declaration, and therefore does not translate into actual implemented behavior.

The particular controversy is raised by advising customers to purchase financial products with a high risk, of which the client is not sufficiently informed. An example might be the encouragement of 10,000 Deutsche Bank customers with a high return rate (10\%) to invest (DM 160 million) in a company to build Ferris wheels, and which later became bankrupt. The bank refused to financially support the company for this purpose, because it believed that the project had too high a risk. The bank offered $60 \%$ reimbursement of the amount invested, which was accepted by 9,000 customers. One client went to court in Frankfurt am Main, which ordered the bank to refund the entire amount plus interest (Bart 2011).

Even less ethical methods were applied by Citigroup, urging customers to buy securities based on housing loans, while the bank itself was predicting a slump. The resulting customer pleas were considered by the Securities and Exchange Commission. The Bank will end up paying \$285 million for settlement on civil charges of fraud. This allegation is neither denied nor admitted by the bank (Biznesowy 2011). 


\section{An example of ambitious ethical standards}

Achieving the first level of ethical behavior (ethical awareness) is not possible without ongoing monitoring, identifying the persons responsible for compliance with the rules and the inclusion of ethical behavior to the reward (and punishment) system. As the example of General Electric shows, when a culture based on ambitious and unwavering ethical standards is implemented successfully by the leaders like Jack Welch and Jeff Immelt, it was necessary to fulfill the following conditions:

- Involvement of management, because "in none of the areas of leadership commitment to corporate life is it so important as in the area of creation of a culture based on ethical proceedings" that are expressed in consistency in public and private life, attitudes and behaviors.

- Respecting certain ethical standards for employees at all levels and consistent punishment for misconduct in relation to ethics, including the sanction of dismissal.

- Determining the guardians of ethics in business, who in GE were the managers of the finance, legal and human resources departments (it is not recommended to create additional departments for this purpose). The responsibility for ethical behavior rests with the managers of business units.

- Creation of communication channels in the ethical issues that promote the transmission of information about unethical situations. Channels may include advocates of ethics in business; annual evaluation of each business unit for actions involving ethical principles; internal auditors to inspect compliance with legal, financial and ethical standards; and managers of finance, legal and human resources departments. The company immediately discusses everything that is praiseworthy and reprehensible. In the annual survey of employees, they can express their opinion whether they agree with the statement "In this company there is no compromise when it comes to ethical business conduct."

- Educating employees on the applicable ethical principles, rules of using common sense analysis (Heineman 2010), systematic information about changes in finance, law and business ethics, as well as explaining the situation in which employees can be accused of "aiding", "secondary wrongdoing" etc.

Unlocking the potential of ethical action that lies in every person requires, as Freud claimed, imposing reprisals on the instincts and passions (Young 2005: 11). At GE, it is emphasized that the best example of enforcing ethical behavior is to dismiss an employee, or even better a manager, for unethical behavior. The worst is the hypocrisy of ethical behavior announced in public and not respected in everyday professional and private life.

It should not be one-way but a two-way relationship, i.e., the bank-stakeholders and also the stakeholders-bank. Unethical behaviors of clients to banks and banks to its employees should also be taken into consideration. 


\section{The ratings assessing the activities of banks vs. ethics}

One of the major forms of ethical assessment of banks are rankings prepared by various chapters and institutions showing the top banks as the most effective, most caring about corporate governance, socially engaged, best to inform stakeholders, etc. The results of these evaluations are made public, and the banks are rewarded and inform their employees and customers (e.g. by showing information about a first place in the ranking on their website, and photos of the award presentation in internal publications). These rankings may thus become an important educational instrument in the ethical behavior of banks, and promote the banks' adherence to high ethical standards.

The use of published rankings as an excellent means to promote the ethical behavior of banks, however, requires an appropriate selection of indicators and scales assigned to them as the basis to create the rankings. These rankings are not always able to meet the demands of ethical principles, which mean that they might actually encourage unethical behavior.

The ranking of "The best banks", for example, published in "Gazeta Bankowa" raises ethical doubts caused by the weighted importance of particular measures: solvency ratio and receivables from customers in relation to commitment to customers. Solvency ratio is of major importance when its level reaches 10 to 15\% (10 ranking), and then from 8 to 10\% (9 ranking) and from 15 to 20\% (7 ranking) (Styrnik 2011: 22-23). The ranking therefore promotes lower solvency ratios. However, the Polish Financial Supervision Authority (PFSA) wrote to the presidents of all commercial banks with a recommendation concerning use of profits to strengthen the equity of the banking sector and to maintain capital adequacy ratios of at least $10 \%$. This actually meant an increase during the crisis to a minimum level for this ratio from $8 \%$ to $10 \%$. This recommendation has not been revoked, and its binding force is supported by the changes in the level of this index in so-called Basel III. Highly evaluated in this ranking are banks that did not even reach the recommended level of solvency ratio than banks that really cared about their safety, keeping the indicator at a level above $15 \%$.

Similar promotion of unethical behavior can be observed in the case of importance attributed to the interval indicating receivables from customers in relation to commitments to customers. Assigning the highest priority (10 ranking) to the level of this index in the range from 0.76 to 1.25 and above, (8 ranking) in the range from 1.26 to 1.50 , and lower in the range from 0.51 to 0.75 (7 ranking) is not only unethical. It is rather a misunderstanding in a situation where due to liquidity problems, it is advisable in the banking sector to maintain this ratio at level 1.0. To become the best bank in accordance with the rules of this ranking, it is necessary to act rapaciously, ignore the advice of the PFSA and jeopardize the safety of the operation of the bank. This is a deliberate example to emphasize that ethical behavior is not established through a general commitment but with a thousand fold showing of actions. Of course, a more holistic approach to the selection of indicators and the importance assigned to them should be applied to determine a bank as the best, and thus constitute a model to follow as the way to become the best. It would 
also require accepting assumptions to define the best bank, and most of all determining whether the best bank is the one earning the highest profits and gaining effective indicators, or whether the bank is functioning safely and efficiently. Undoubtedly, it should not be the bank not in compliance with safety recommendations.

Other doubts appear when analyzing the ranking of banks according to the quality of service to SMEs. It includes among others a table of "lodged complaints" containing 14 banks' ranking by the number of complaints per SME client. The worst bank indicator showed about 500 times more complaints per one SME customer than for the best bank (apart from some banks with no complaints). Such an indicator does not inform but misinforms, because analysis shows that the basis for calculating this indicator are not comparable data. In a negative light are the banks that manage complaints recorded in information technology applications in which all complaints are logged, and other banks that have registered only a few complaints are presented from a more positive point of view (Doliniak 2011).

Much closer to the promotion of ethical behavior, it would seem, is a ranking of socially responsible companies, and those actively implementing CSR. Of course, it would be better when it is CSR of the era of responsibility (CSR 2.0), and not the era of greed, philanthropy, marketing or management highlighted by Wayne Visser (Bachnik 2011: 7). In each of these approaches, to a lesser or greater extent, the idea of socially responsible companies is used. Legitimization of socially responsible companies cannot be limited only to socially desirable activities, mainly carried out in order to improve the image, without taking responsibility (ethics) for behaviors in other areas not covered by the assessment.

Social responsibility is reserved for single activities that are well documented to be demonstrated to the wider community, while simultaneously the principles of good practice in relationships with employees, customers or other stakeholders not covered by the assessment are neglected or even violated. This raises a lot of controversy, and the annual ranking of responsible businesses (Ranking 2011) is accompanied by a publication “Responsible Business 2011. CSR 2.0." In the foreword to the publication, the editor notes that "the inspiration for this release was a disappointment with CSR understood and used by some companies as a cover for improper or even malicious behavior. In the face of the spectacular failures of companies considered leaders in CSR, this idea disgraced itself" (Piłat 2011: 1).

There are five principles that make up the essence ("DNA") of CSR 2.0 and distinguish it from CSR 1.0 (Bachnik 2011: 8):

- Connectedness - ability to take decisions and to have activities in cooperation with other firms and customers (open source, crowd sourcing) to solve important social and environmental problems, which require transparency and are connected with changes, including business model changes (e.g. Eco-Patent Commons - project of IBM, Nokia, Pitney Bowes, Sony in partnership with World Business Council for Sustainable Development for sharing of intellectual resources to environmental protection); 
- Creativity - concentration on looking for solutions of social and ecological problems of the world (e.g. Muhammad Yunus conception of mini credit) in opposition to looking for standards and procedures in CRS 1.0 (e.g. introducing of the social dialog with stakeholders in the firm, according to international standard AA1000SES or preparing the code of ethics for the institution);

- Scalability - expanding the good praxis of individual entrepreneurship to undertakings on a world scale;

- "Glocality" - thinking globally but acting locally;

- Circularity of Design - projection of so-called systems "cradle to cradle" (e.g. building of houses that produce more energy than they consume; the goal of Wal-Mart is reduction of waste to 0 and to use up to $100 \%$ of only renewable energy).

However, the rankings of the responsible businesses (they also include financial institutions) are in every respect worthy of promotion, because they show the actual ethical behavior of individual enterprises. It would be advisable, however, to slightly reorient and enrich the basis for the ranking (towards CSR 2.0). A responsible behavior in their core business should be much more important. To be among the companies highly ranked should also require certain efforts, for example not being accused of unethical advertising, pollution, etc. Rankings should be made more transparent, since presenting only the scores in the five areas (responsible leadership; dialogue with stakeholders; community involvement; responsible management; social innovation) does not allow for a fuller assessment of the methodology.

Using the rankings that are methodologically well prepared and do not raise common controversy in promoting ethical behavior of banks is crucial in building a positive image of banks, especially during the rapid decline of trust in these institutions. In 2011, the confidence in the banks rapidly fell (from $44.4 \%$ in 2009 and $53.9 \%$ in 2007 to $20.8 \%$ ). Also for the first time, the percentage of respondents expressing confidence in the banks was lower than the percentage of respondents declaring lack of confidence (30.0\%) to banks (Czapiński 2011: 188).

\section{| Conclusions}

Shaping ethical behavior is a long-term, holistic process, embedded in performing daily duties, preferably in an environment with high morale (learning through a good example). Business lacks unambiguously positive role models, and thus unquestionable values, principles, procedures, etc. In most banks the existing business models, rules or the books of best practices reviewed perhaps one day a year by the employees to discuss how to properly understand them, are in fact far from daily routine. Human resources departments that prepare them at the same time accept the employment of workers, mainly young people on the basis of several months' contracts, depriving workers of the rights to annual leave, pension contributions, paid sick leave, etc. Modern methods of staff management do not always dictate ethical behavior of employers towards employees, which further translates into unethical behavior of employees towards customers. 
Ethical behaviors in the banks, despite the high awareness of moral norms, are largely declarative rather than actual. In order to approximate the actual behaviors to the declared ones, we need to introduce further improvement of methods and instruments in ethics education. We also must encourage the implementation of management practices consistent with ethical behavior, starting with redefinition of the functioning of the bank, i.e. broadening the task of achieving ambitious outcomes by adding respect for ethical standards.

R e f e r e n c e s

Bachnik K. (2011) Rewolucja w CSR. Conversation with Wayne Visser. Harvard Business Review. Polska - Odpowiedzialny Biznes 2011. CSR 2.0, p. 7.

Bart (2011) Diabelski interes Deutsche Banku. Gazeta Wyborcza, 26 October 2011.

Best Global Brands 2011, www.interbrand.com (23.10.2011).

Biznesowy przegląd tygodnia. Rzeczpospolita, 24 October 2011, p. B8.

Czapiński J., Panek T. (eds.) (2011) Diagnoza społeczna 2011. Warunki i jakość życia Polaków. Warszawa: Centrum Rozwoju Zasobów Ludzkich.

Czubkowska S. (2009) Oszukujemy klientów, by wyrobić plan. Dziennik, 1 June 2009.

Doliniak K. (2011) Cenimy przejrzystych. Forbes, October 2011.

Garapich M. (2003) Mniejsze banki oferują korzystniejsze warunki. Parkiet, 18-20 November 2003.

Gasparski W. (2008) Responsible Management Education. In: Gasparski W., Responsible Management Education. Warszawa: Wydawnictwa Akademickie i Profesjonalne Spółka z o.o./ Akademia Leona Koźmińskiego.

Heineman B. (2010) W., Jak nie wpadać w pułapki etyczne? Harvard Business Review. Polska, April 2010.

Kieżun W. (2008) Idealny typ sprawnego menedżera i metody jego odpowiedzialnego kształcenia. In: Gasparski W. (ed.), Odpowiedzialne kształcenie menedżerów. Warszawa: Wydawnictwa Akademickie i Profesjonalne Spółka z o.o./Akademia Leona Koźmińskiego, p. 68

Kuk M. (2010) Nieliczne wnioski o zmianę konta. Dziennik Gazeta Prawna, 4 February.
Ossowska M. (2005) Socjologia moralności. Zarys zagadnień. Warszawa: Wydawnictwo Naukowe PWN.

Piłat K. (2011) Odpowiedzialny Biznes 2011. CSR 2.0. Harvard Business Review. Polska - Odpowiedzialny Biznes 2011. CSR 2.0, p. 1.

Piotrowski, M. (2011) Olympus od lat retuszował straty. Gazeta Wyborcza, 9 November 2011.

Porter M. (1992) Strategia Konkurencji. Metody analizy sektorów i konkurentów. Warszawa: PWE.

Przybylski J. (2011) Klienci w USA wygrali z bankami bitwę o opłaty. Rzeczpospolita, 3 November 2011.

Przybylski J. (2011) Bunt przeciw bankom. Rzeczpospolita, 7 November 2011.

Ranking CSR 2011. Dziennik Gazeta Prawna, a suplement from 14 April 2011.

Simon, H., Zinoecker W., Gorzeń R. (2009) 15 taktyk prowadzących do szybkich wygranych. Harvard Business Review. Polska, April 2009.

Stec A. (2011) Parada pechowych maklerów. Puls Biznesu Weekend, 7 October 2011.

Styrnik B. (2011) W poszukiwaniu konkurencyjnej przewagi. Gazeta Bankowa, July/August 2011, p. 22-23.

Welch J., Welch S. (2005) Winning znaczy zwyciężać. Warszawa: Wydawnictwo Studio Emka.

Young S. (2005) Etyczny kapitalizm. Wrocław: METAmorfoza.

Zdanowska J. (2011) Zasady dobrych praktyk bankowych oraz kodeksy etyki w wybranych krajach Unii Europejskiej. Komisja Etyki Bankowej przy ZBP, typescript, Warszawa, August 2011. 